\title{
Artist and Collective Subject: Adorno on Subject of Art
}

\author{
Feng Tao ${ }^{1, \mathrm{a}^{*}}$ \\ ${ }^{1}$ College of Philosophy, Nankai University,_Tianjin,300371 6, China \\ ${ }^{*}$ Corresponding author-= Email: taofeng @mail.nankai.edu.cn
}

\begin{abstract}
According to Adorno, in art process there are at least two subjects including the artist and the collective subject. Artistic language is the translation of natural language, and artists are the agents of natural things. Only those artists who can successfully translate the language of things into the language of art can be regarded as genius. Artists are producers, but art production has certain freedom and equality. The collective subject is the initiator of the process of artistic expression, for which the artist speaks. The relationship between collective subject and artist shows that subject is the agent of object. Subject and object are the intermediaries of each other. Artistic activities embody the equal relationship between subject and object.
\end{abstract}

Keywords: artist, collective subject, Adorno, subject, agent

\section{INTRODUCTION}

According to Adorno, a German thinker and representative of Frankfurt school, there are two subjects of artistic activities: Artists and collective subject ([D]kollektives Subjekt). Artists are the actual producers of artworks, and they are "I"; while "collective subject" are the people and things that participate in artistic expression together, and they are "We". Adorno thinks that the real subject of artistic language, more precisely, the speaker of language, should be "collective subject", but this kind of collective subject is not a transcendental abstract universal subject, but a subject composed of many concrete people and things. These concrete people and things are the oppressed unidentified. They need to make their own voice through artistic language, and therefore the artist becomes the agent of translating the thing's language into the art's language.

I want to point out that although this kind of collective subject is the initiator of the language of thing, it is not a kind of cognitive subject, on the contrary, it is the object known by the artist. The artist is the subject in the artistic creation activities. In Adorno's view, the object is primary, the object has subjectivity, and the subject also has objectivity. As the object, the collective subject is active and primary. The artist, as the subject, is the agent of the object.

\section{ARTIST: GENIUS AND AGENT}

Adorno believes that art activities are cognitive activities. Art is a form of knowledge in essence, but this kind of knowledge is different from the general reasoning knowledge. Compared with the materialized concept knowledge, Adorno pays more attention to art as a form of knowledge. Art transcends the opposition between the subject and the object through an expressive-mimetic language, and realizes the equal and intermediary relationship between the subject and the object.
Adorno also believes that art is a kind of production activity, that is, the practical activity of artists producing art. K. Marx claims that art is a special form of production, which is dominated by the general law of production. Adorno inherits this view. He believes that in the production of art, the relationship between artists and works of art is just between workers and products. But this production relationship is a more free than other forms of labor. Artworks are neither dominated by artists nor alienated with workers making them.

In Adorno, there are similarities between art as a cognitive activity with as a production practice activity. Only when the transformation of cognitive activity is realized, it is possible to achieve the transformation of production activity. In these two kinds of activities, the relationship between the subject and the object is equal and reconciled instead of dominant.

After we have made clear the recognition and production practice as the essence of art activities, we will subdivide the process of art activities. Art activities can be divided into creation process - the process of artists creating artworks (this process includes artists understanding of materials) and appreciation process - the process of audience appreciating artworks (this process is the process of audience understanding of artworks).In the process of creation, the subject of cognition is artist, the object of cognition is material (including things and people as material); in the process of appreciation, the subject of cognition is audience, and the object of cognition is artwork.

\subsection{Genius}

G.Lukacs, a Marxist scholar, pays great attention to the class nature of artists and claims that the class of artists determines the essence of his works. W.Benjamin believes, in his article The Author as Producer, that artist could not become proletariat because "the bourgeois class gave him a means of production" in the form of his culture. However, 
artists can attract the proletariat to art production by providing advanced production tools for the proletariat, and this apparatus is able of making coworkers out of readers or spectators. [1]

Adorno is not concerned with the class of the artist, which will certainly affect the way of looking at things, but not necessarily affect the truth content([D]Wahrheit Gehalt) of the art works. For example, like the bourgeois F.Holderlin and R. Wagner, Adorno believes that the works of Holderlin have the truth content, and Wagner's works are false. This is because Adorno believes that artists are basically just processors and translators, not creators. The real original voice is the expression of things. When an artist follows the logic of things expression, he can really know things, and the artwork he creates has the truth content, otherwise, he does not know things, the artwork is false. The artist who knows the non-identity of things and creates the truth content of art has "the genial", which is a kind of talent. Adorno believes that genius means that he can occasionally find the constellation and reach the object subjectively [2]. In Kant's view, genius is a kind of talent that provides rules for art and makes laws for art. He said: " Genie is the innate ingenium through which nature gives art the rule."[3] Kant emphasized two points: Firstly, genius has originality, is a model. Secondly, genius is a natural characteristic, and nature provides rules for art through genius. Obviously, Adorno inherited Kant's view to some extent. He said that "genius itself is also nature". [4] Genius is a kind of spirit as well as a kind of nature, so it can be the intermediary between spirit and nature. There is a reconciliation between nature and spirit, and the cycle of enslavement and domination of nature is eliminated. Only artists with such talents can create authentic artworks. But this kind of gifted artist is not the original, rather the expression of things is the original. Adorno believes that if we want to save the concept of genius, we must separate it from " crude equation with the creative subject "[5]. The artist is just to transform the expression of things into the language of art. The artist with genius can successfully realize this transformation according to the logic of art itself, that is, the logic of the language of things.

The creation process of art is also a cognition process. Artists need to understand things (including materials) and translate thing's language. To understand the things' language is to imitate the things' language and turn it into an artistic language. It includes simulating the logic of the things' language and transforming the content of things' expression into the content of artistic expression. Here things include materials and the objects observed by artists. Materials include not only raw material but also matter, that is, things, people and society depicted by works of art. Artists focus on the logic structure and linguistic characters in transforming things'language, while artists focus on the materiality of things in objectifying and formalizing materials. When Adorno talks about how art imitates natural beauty (Natural Language), he means to imitate the language of things. When he talks about how artists formalize and shape materials, he means to integrate materials. In fact, this is two different aspects of a process. Therefore, the artist is undoubtedly the main body in the art creation activities, the artist has certain initiative, the artist's subjective impulse is essential in the art creation.

\subsection{Agent}

Benjamin once put forward the view that "the author is the producer". He thought that the author is the executor of art production. The function of an artist is to educate other artists and audiences through art. He said: "an author who teaches a writer nothing, teach nobody anything. [6] Benjamin believes that it is not so much the content and meaning in the artwork to influence others, but rather the artist provides a better creative means and equipment. The artist leads the audience to participate in the art production activities, making them become the participants in the art production activities. Benjamin also stressed that we should break the barriers between bourgeois artists and proletariat through improving productivity, so that they can unite together. That's why Benjamin so emphasized the liberation of mechanical reproduction of art. In Benjamin's view, the artist has become a moment who is the subject of art production, but whose role is to lead others to participate in art production.

Adorno also inherited this theory of art production. He proposed the concepts of "aesthetic productive force" and "aesthetic productive relationship". In aesthetic productive relationship, artists are producers and workers, and the materials in art are means of production. But different from the actual production relations, artists as workers are free when dealing with means of production, and their labor is relatively free. Works of art are the labor products of artists. Artists can own products after they produce labor products, and the labor value of artists will not be reduced to surplus value. But Adorno's aesthetic productivity does not regard art production as an industry. On the contrary, Adorno is against the industrialization of art. He emphasizes the technology that art develops according to its own logic of things. This technology is to show the truth content of art language, and is totally against mechanical reproduction. Adorno believes that mechanical reproduction is different from imitation or simulation. Mechanical reproduction is only a kind of superficial similarity, which does not pay attention to the uniqueness and linguistic character of art. Adorno affirmed the producer status of artists, which does not mean that artists are the subject of artistic language expression. Obviously, Adorno hesitates to identify the subject qualification of artists. He thought "the artist's act is the minimum". [7] Adorno considers artists as the undertaker and agent of the art activities. What is the real subject of artistic expression? Adorno thinks that it is a kind of "social subject". Artists are just the spokesman or even the voice tool of social subject. Artists - who are bearers of works of Art - are not the individuals who produce them. Artists become representatives of the whole social subject through their work and passive activities. [8] Adorno wants to minimize the influence of individual artists on works of art. He believes that the influence is accidental and subjective, which is in conflict with the objectivity and logicality of works of art. For this reason, Adorno needs to 
weaken the genius characteristics of artists and emphasizes the natural characteristics of genius because he is afraid that the concept of genius will be evolved into a kind of privilege and fascist ethnology. Adorno believes that the subject is not the most important in the process of art. Artwork is not the product of an artist, but the result of an artist's aesthetic synthesis according to their own logic of materials and matters. Adorno believes that the real artistic process and the manifestation of truth content are actually the spontaneous process of things and the process of things expressing themselves. That is why Adorno said that artists are only a kind of agent.

\section{COLLECTIVE SUBJECT}

In Adorno's Ästhetic Theory, the concepts of subject and object are often used beyond epistemology. The most typical example is Adorno's "collective subject" - the compound historical and social subject. Adorno described the collective subject as a "we" rather than "I" to emphasize the subject's sociality and objectivity. "Society, the determinant of experience, constitutes the works as their true subject". [9] At the same time, Adorno also emphasized the historicity of the collective subject. He thought that the concept of subject was subtly tuning and revising constantly, which was a process of historical accumulation. The subject is not an eternal concept, and the collective subject is actually the expresser -- the initiator of expression behavior. Adorno regarded the initiator of this behavior as the real subject of art. "The linguistic character of art leads to the reflection of what speaks of art; the real subject is not maker and not the recipient". [10]

In Noten zur Literatur and Ästhetic Theory, Adorno pointed out many times that artists are not the real subject of art, but a kind of deputy or intermediary. I think it should be explained from several aspects. First of all, Adorno uses the category of subject and object at different levels. He sometimes confuses the subject and object in epistemology with the initiator of behavior. For example, he puts forward the concept of "collective subject" (he called it "social subject" in Noten zur Literatur), which is the real subject of art. I think the so-called "collective subject" is actually a kind of sociality of artists as the subject. Even if it is called "subject", it is not the subject in the sense of cognition, but rather the initiator of artistic expression. Secondly, Adorno emphasizes the collective subject while weakening the artist's subjective intention, which is to reduce the subjectivity of the subject and emphasize the objectivity of the subject. The initiator of artistic expression is not the subject, but rather the object, because the object is the primary in Adorno's view. Thirdly, Adorno's subject and object are dialectical. The subject obtains objectivity from the object, and the object obtains subjectivity from the subject. If we regard "collective subject" as the object of epistemology and artists as the subject of epistemology, we can clearly see that artists as the subject are influenced by the collective subject as the object, so there are more objective factors. On the contrary, collective subject needs to express itself by the subjective impulse of artists. Adorno said in discussing the relationship between subject and object: "subject is the agent of object, not the constituent of object".[11] So in fact, in Adorno's view, the subject is the agent of the object. Now we can understand why Adorno said that the artist is the agent.

To sum up, we can see that the collective subject is the initiator in the process of artistic expression, but the collective subject needs the help of artists to articulate. If art creation is regarded as a kind of cognitive activity, the artist is the subject, while the collective subject and art materials are the objects. The collective subject constitutes the objectivity of the artist at the same time and they will affect the artists and finally participate in the creation process.

\section{SUMMARY}

From the above analysis of artists and collective subjects, in art activities, including art creation activities and art appreciation activities, the relationship between the subject and object is an equal relationship: the subject imitates the object rather than dominates the object, and the subject and object are mutually mediated, dialectical coexistence, the subject has objectivity, and the object also has subjectivity. This is an ideal relationship between subject and object, which is the correction and redemption of the subjectoriented relationship of subject- object. It is in this sense that Adorno believes that art knowledge can redeem traditional inferential knowledge and aesthetic rationality can correct instrumental rationality.

\section{ACKNOWLEDGMENT}

This paper was supported by the National Social Science Fund of China and the name of this project is "The Language Thought in Adorno's Philosophy" under grant No. 16BZX118.

\section{REFERENCES}

[1][6] W.Benjamin, "The Author as Producer". trans, John Heckman, New Left Review I/62, July-August. 1970. p.68,p.6

[2][5][7][9][10] T.W.Adorno, Gesammelte Schriften, Band 7: Ästhetische Theorie, Hg. R.Tiedemann, Frankfurt am Main: $\quad$ Suhrkamp 1970. P.256,p.254,p.249,p.134,p.249

[3] I.Kant, Werkausgabe X: Kritik der Urteilskraft, Hg.W. Weischedel. Frankfurt am Main: Suhrkamp,1974. pp.241242

[4][8] T.W.Adorno, Gesammelte Schriften, Band 11:Noten zur Literatur. Hg., Rolf Tiedemann, Frankfurt: Suhrkamp. 1974. p.491,p. 126 
[11] T.W.Adorno, Gesammelte Schriften, Band10.2:

Kulturkritik und Gesellschaft II. Hg., Rolf

Tiedemann.Frankfurt: Suhrkamp.1977, p.752 